\title{
REMARKS ON THE CONCEPT OF WIND IN THE TEXTS OF THE TEMPLE OF ESNA
}

\author{
Mohammed A. ELSAYED \\ Lecturer, Faculty of Archaeology, Fayoum University Egypt \\ E-mail: mas02@,fayoum.edu.eg
}

\begin{abstract}
This paper focuses on the concept of wind in the texts of the temple of Esna. It presents a detailed analysis regarding the wind in the ancient Egyptian representation. It investigates the function of the wind in the different contexts and the deities who were linked to it in the temple of Esna.
\end{abstract}

\section{KEYWORDS}

Wind, Breath of life, Esna, Khnum Shasehotep

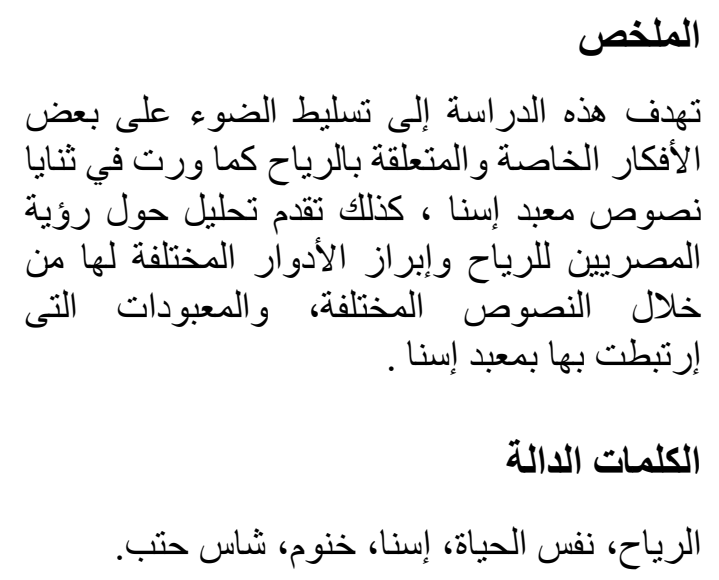

\section{INTRODUCTION}

The scope of this paper is limited to the discussion of the concept of the wind at Esna temple. Two different terms indicated the wind, $t 3 w^{1}$ and $n f^{2}$. They vary in nature between the hymns which were dedicated to Khnum, the main god of the temple and one of the minor deities, the offering texts ${ }^{3}$ and sometimes the processions of the Hapy. ${ }^{4}$ The study presents a detailed analysis of the wind in the ancient Egyptian representation by trying to know the original source of the wind and which way it blows in the ancient

\footnotetext{
${ }^{1} \mathrm{~Wb}, \mathrm{~V} 350(12)-352(29)$.

${ }^{2} \mathrm{~Wb}$, II 250 (15-18).

${ }^{3}$ One of the most offerings linked to the wind in the temple is the plumed crown. Here the double plumes crown equaled with wind upon the head of god: see, Esna VI, 512. The plumes of this crown are depicted usually as the four forms which could indicate the four winds: see, Esna VI, 512, 1; Haikal, F., "An Unusual Ostracon from The Beit El-kretleya Museum", in: Hommages a' Jean-claude Goyon, IFAO, 2008, 242-245.

${ }^{4}$ As the source of the country's prosperity which comes annually with the inundation and life to all beings see, Esna II, 54, 16; Edfou VIII, 154, 10.
} 
Egyptian mind. Furthermore it investigates the religious functions of the wind and the gods and goddesses connected with it.

\section{The original source of the wind and which way it blows}

According to the following texts, the wind is usually blows by Khnum and Osiris as it began in the first time as a kind of combination of the attributes of Shu and Tathenen:

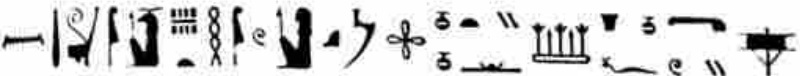

$N \underline{H} n m-P t h-\breve{S} w k m 3$ wnnw $\check{s}^{\top} \cdot n . f \underline{t} 3 w$.

"O, Khnum-Ptah-Shu, who created the existences, who began the wind".

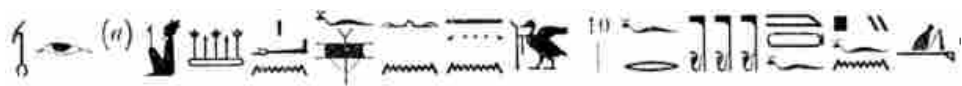

Wsir š3 nfw nn t3 $n$ km3.f r ntrw ntrwt $m$ rn.f pfy $n$ T3-tnn.

"Osiris, who began the wind, when there was no earth he created yet for the gods and goddesses in his name Tathenen".

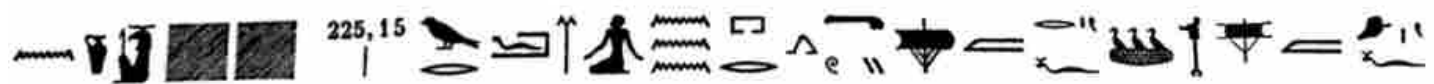

$N \underline{H} n m[\ldots]$ wr pr $m$ Nwn pr țis $m$ r.f $m h \underline{w}$ m fnd.$f$

"O, Khnum [...], the great one who came forth from Nun, the wind came forth from his mouth (and) the northern wind from his nose".

A text from Edfu shows that the four winds came forth from the nostrils of Horus. The text reads:

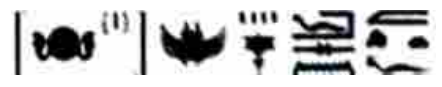

Nswt-bity 'py ţ3w 4 pr.sn $m$ fnd.f

"The king of Upper and Lower Egypt, winged solar disc, the four winds ${ }^{4}$ came forth from his nose". 5

\footnotetext{
${ }^{1}$ Esna III, 225, 40. The same idea is attested at Kom Ombo with Sobek by saying: $n t k b 3 \breve{S} w \underline{t} 3 w$ di tp.fm $3 h t$ "you are ba of Shu, the north wind who shows himself in the inundation season". See Gutbub, Kom Ombo, 1995: No. 192; De Morgan, Kom Ombo, No. 795.

${ }^{2}$ Esna VI, 494, 9-10.

${ }^{3}$ Esna III, 225, 39, 40.

${ }^{4}$ For the four winds which were represented in the Ptolemaic and Roman temples see, Gutbub, Kom Ombo, 328-353; De Morgan, Kom Ombo, 169, No. 217; De Morgan, Kom Ombo, 1909: No. 938; Gutbub, Kom Ombo 329, fig. 126a: Woodhouse, S., "The Sun God, His Four Bas and the Four Winds in the Sacred District at Sais: the Fragment of an Obelisk (BM EA 1512)", in S. Quirke (ed.), The Temple in Ancient Egypt. New Discoveries and Recent Research, London, 1997, 133; Gutbub, A. "Die Vier Winde im Tempel von Kom Ombos", in Keel, O. (ed.), Jahwe-Visionen und Siegelkunst. Eine neue Deutung der Majestaetsschilderungen in Jes 6, Ez 1 und 10 und Sach 4, Stuttgart, 1977, 328.; De Wit, "Les génies des quatre vents au temple d'Opet", Chron Eg 32, 1957, 25-29.; Riggs, Ch., "Archaism and Artistic Sources in Roman Egypt. The Coffins of the Soter Family and the Temple of Deir el-Medina", BIFAO 106 (2006), 315-332; Gutbub, A., "Die vier Winde in Ägypten", in: Othmar Keel (ed.), Jahwe-Visionen und Siegelkunst, Eine neue Deutung der Majestatsschilderungen in Jes. 6, Ez 1 und 10 und Sach 4, Stuttgarter Bibelstudien 84/85, Stuttgart: Verlag Katholisches Bibelwerk, (1977), 328-353.

${ }^{5}$ Edfou III, 19, 18: See also V, 268, 3-4.
}

\footnotetext{
- 83 - $\mid$ Remarks on the Concept of Wind in the Texts of the Temple of Esna
} 
Khnum of Esna is also regarded as a primeval $b a$ that gave the first breath for himself by himself and then created the four winds of the four directions:

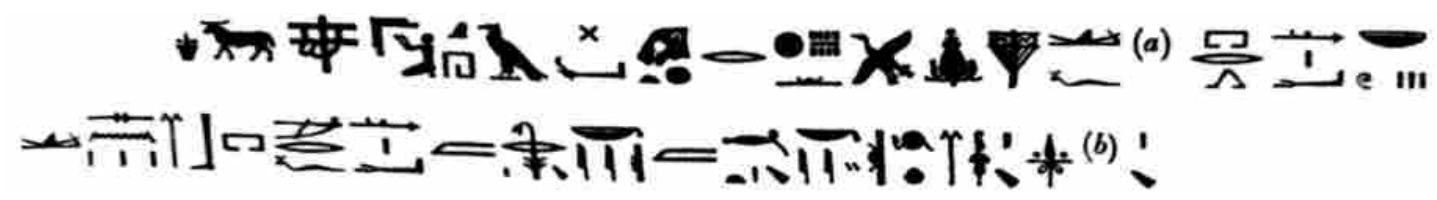

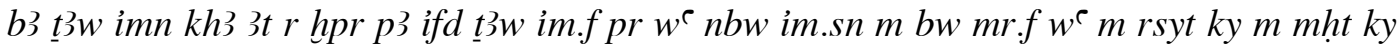
$r^{\mathrm{e}}$-nb imntt i3btt.

"The $b a$, the hidden wind, strong in the moment of attack, who created the four winds from himself, all ones from them are coming forth to the place where he loves, one for the south, the other for the north and the other ones are daily for the west and east".

Furthermore, an inscription shows that the wind came forth from the throat of Khnum:

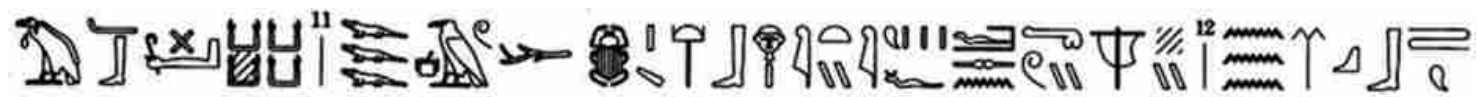

Nhp k3w ntrw s3w t3 ndb hr ndb.wy.f pr.sn țw mw m kbbt.f.

"Who fashioned the kas of gods, branch of earth, the whole earth is upon his two wings, they make the wind and water is coming forth from his throat".

As for the ceramicist, Khnum of Esna, he shaped the created beings on the pottery's wheel. He took breath of life force as a wind coming forth from his mouth:

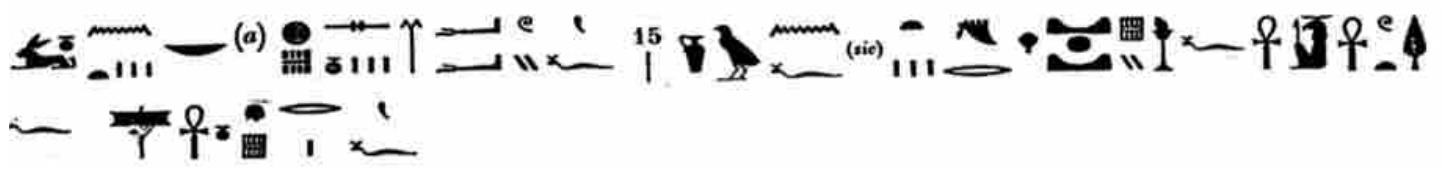

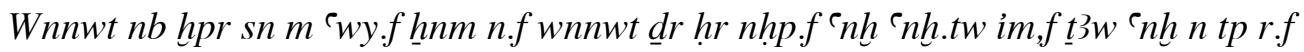

"All existences, he created them upon his two arms, he fashioned all the existences upon his pottery wheel, the living one who gives life from him, the wind of life is upon his mouth". 3

Two texts indicate the role of Khnum of Esna and a subordinate deity, Shuemhery, fastening onto and holding the wind in their fests in order to breeze all of beings. These two texts read:

\footnotetext{
${ }^{1}$ Esna III, 377, 2.

${ }^{2}$ Esna VII, 628, 11, 12.

${ }^{3}$ Esna II, 70, 14, 15; III, 225,14. I inclined that this sense is linked to pushing the wind by tailing the two lips together as it shown in the sign (D135) $§$. This could be compared with a text from Dendera which describes Hathor reading pr TAw n anx im spty.s. "the wind which comes forth from her two lips", see Dendera IX, 96,5. This force of life which the primeval god breathed it into the man to animate him is defined as the spirit of god in the holy Bibble,:see John 20:22 and in the holy qura' $n$ see, Alsadjda: 19.
} 


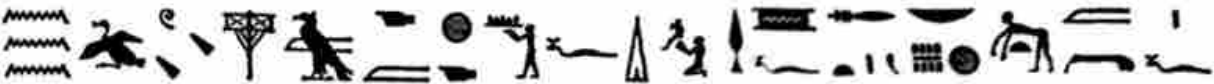

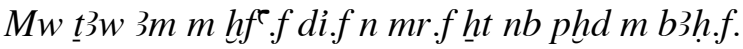

"Water and wind are held in his fest, he gives to whom he loves and to everybody (who) bent down before him",

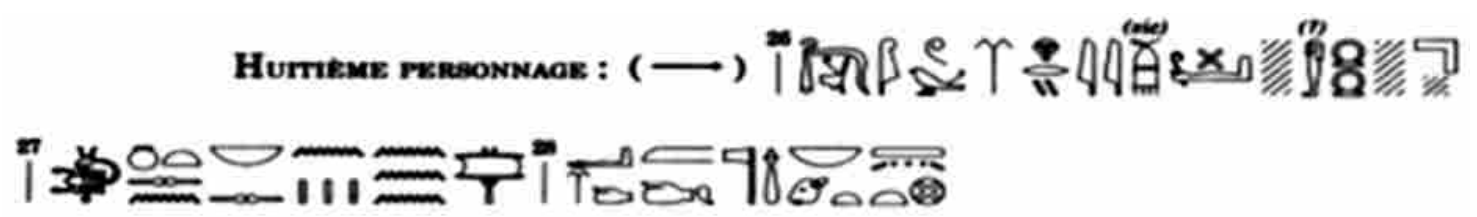

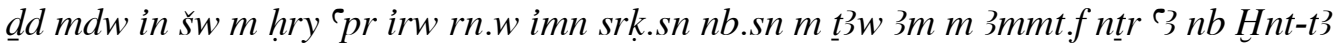

"Words spoken by Shuemhery, who endows forms and names, the hidden ones, all of them are breathed from the wind which is held in his fist ${ }^{2}$, the great god, and lord of Khent-ta"3.

Here I think that it does not mean literarily that the wind is in the fest. The Ancient concept may relate to the divine will. I mean that the wind can be breezed by a gesture of goodwill. This picture can be asserted through the following sentences:

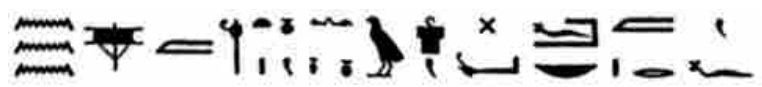

$m w \underline{t} 3 w$ m $w \underline{d}$ t.f nn sỉ pr $n b m$ r.f.

"water and the wind are by his order. There is no time for what all coming forth from his mouth". 4

Also one of the texts reads:

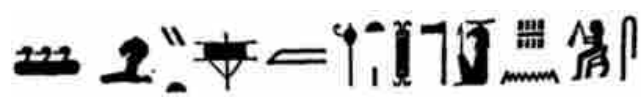

$m h t$ t $m$ wd $t$ n ntr pn šps.

"The northern wind is by the order of this noble god". 5

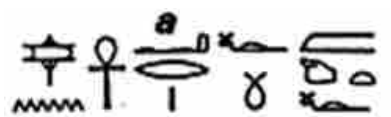

t3w n 'nh di r.f'rfm 3mmt.f.

"Breath of life, which his mouth gives, held in his fest". 6

1 Esna III, 387, 5. See also the same sense, Esna III, 355, 8.

${ }^{2}$ The same sense is attested in one title comes from Dendera see, Dendera XI, 198, 5.

${ }^{3}$ Esna VII, 613, 26. The sense is attested with the lord of Mesen at Dendera as TAw m Ammt.f. "the wind is in his fest", see, Dendera XI, 198, 5..

${ }^{4}$ see Esna III, 395, 28. Also Mut is described in one title as dit TAw $\mathrm{n}$ anx $\mathrm{r}$ fnD $\mathrm{n}$ mrwt.s. "she gives the wind of life to whom she loves", see Sauneron, S., Porte Ptolèmaïque, tf. 12, Nr.14, Z1.16.

${ }^{5}$ Esna III, 387, 4.

${ }^{6}$ Edfou II, 28, 6. See also Edfou IV, 290, 14.

\footnotetext{
- 85 - $\mid$ Remarks on the Concept of Wind in the Texts of the Temple of Esna
} 
In the version, which is attested only at Edfu temple, the text shows that the wind existed by the fire which came from the mouth of Horus Behdety. It reads:

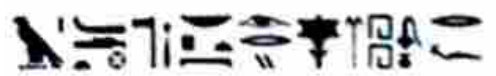

Hr Bhdty ntr ${ }^{3}$ nb pt iry $\underline{t} 3 w$ m hh $n$ r.f.

"Horus Behdety, the great god who created the wind by the flame of his mouth".

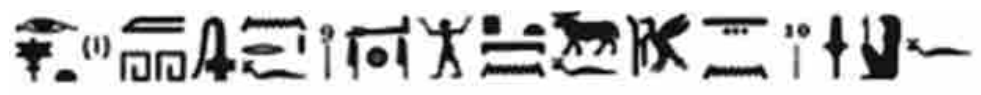

Ir țw m hh $n$ r.f Chy pt $n$ b3.f km? t3 $n$ shm.f.

"who creates the wind by the flame of his mouth, who raises the heaven up for his $b a$ and creates the land for his form". 2

In other context comes with a subordinate deity from Edfu as:

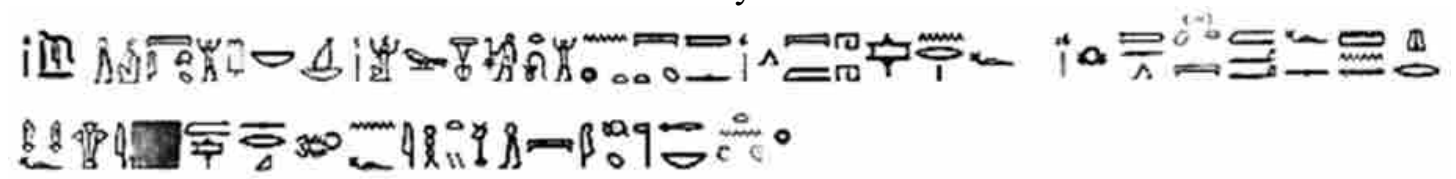

dd $m d w$ in In-hry $\breve{S} w$ s3-Re $k 3$ šwty $n b$ wrrt Hh wr sm3sw tw3 nnt ts pt $m$ hh $n$ r.f nswt-

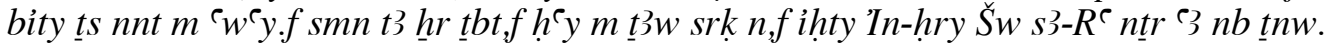

"Words spoken by In-Hery Shu, son of Re, lord of the white crown, Heh, the great one, who raises the sky, who lifts up the heaven form the breath of his mouth, king of Upper and Lower Egypt, who raises the sky on his two arms and places the earth beneath his sandals, who comes like the breath to make the throat breath from him, In-Hery Shu, son of Re, the great god, lord of lifetime". 3

\section{The religious functions of the wind}

1- Wind was the primeval power of the creation. Khnum of Esna and Khnum of Shasehotep were the creators of all the manifestations of life from the wind which came forth from their mouths.

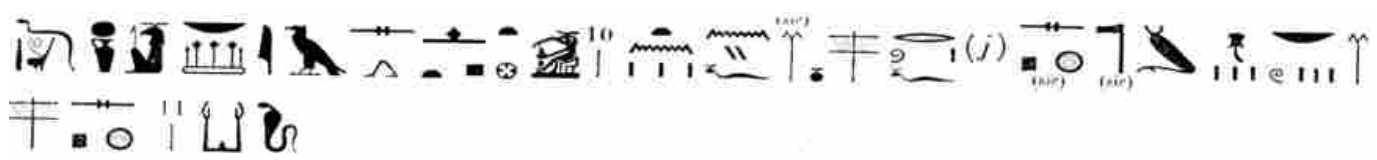

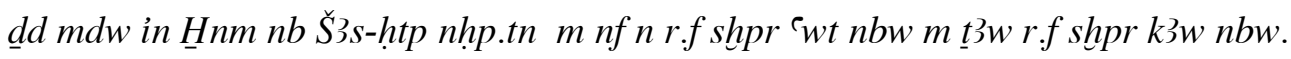

"Words spoken by Khnum, lord of Shasehotep", who creates you from the wind which he breathes from his mouth, he creates all the animals from the breath of his mouth, he creates every $k a " .5$

${ }^{1}$ Edfou III, 19, 14; see also, Edfou VIII, 103, 15, 16.

${ }^{2}$ Edfou VII, 134, 14.

${ }^{3}$ Edfou I, 314, 4-7.

${ }^{4}$ This city is the capital of the $10^{\text {th }}$ nome of Upper Egypt. It is located at the western bank of the Nile a few kilometers to the south of the modern city of Assyut. For more see, Saunerone, S., "Villes et legends d'Egypte", BIFAO 62 (1962), 33-37.; Montet, P., Geographie de l'Ancienne, II, p.125.; Kurth, D., Edfou VII, 600; Edfou VI, 220 (1).

${ }^{5}$ Esna VI, 510, 9-10. The same meaning occurred in Esna III, 328, 5. This concept is also known from Kom Ombo. The primeval Sobek was represented as: tAw smsw sxpr wnnt TAw $n$ anx [...],"the eldest 


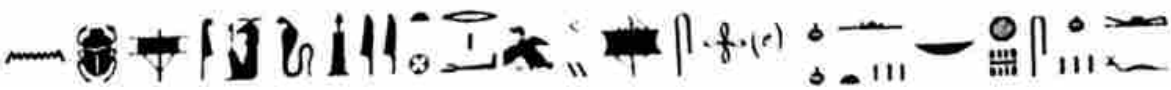

$N \underline{H} n m$ nb 'Iwnt rdi țiw s[hpr] wnnw nb hpr sn im.f.

"O, Khnum, lord of Iwnyt, who gives the wind in order to create all the existences, they are created from him".

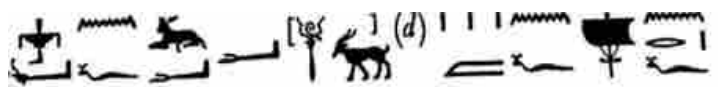

Nbi.n.f `wt $m$ nf.n r.f.

"He created the animals from the wind of his mouth". 2

2- Wind is a vital force which makes the plants to bloom or grow :

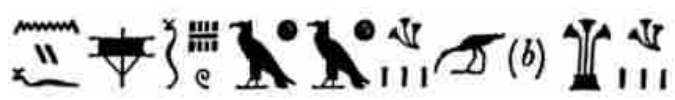

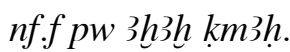

"This is his wind which makes the branches bloom". 3

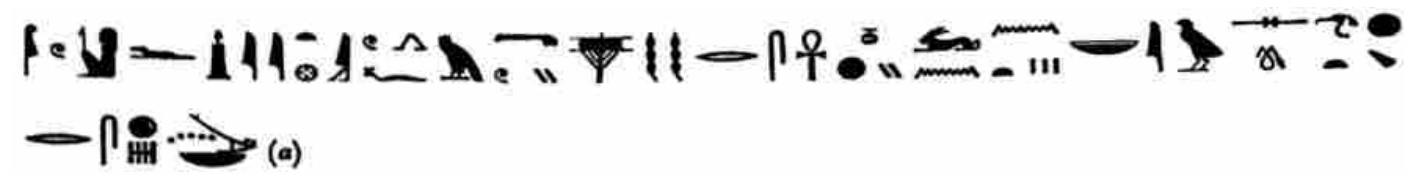

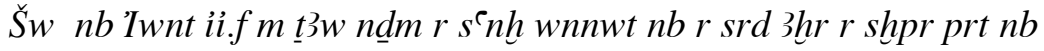

"Shu, lord of Esna who comes as a sweet wind to make all the existences live and to cause the field grows and to cause the creation of all the seeds". 4

3- Wind is the force which makes the grain ripen fully:

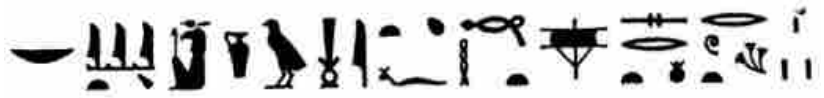

Nb sht hnm snt.f mht țisw (r) srd rwiw.

"Lord of the field, who created his sister and the northern wind to grow the straw". 5

wind which creates what exists, the wind of life [...]". See Gutbub, Kom Ombo no. 160. SERaT Scene No. 210381.

${ }^{1}$ Esna III, 225,14.

${ }^{2}$ Esna II, 17, 32.

${ }^{3}$ Esna II, 366.(6-8). ; V, p.172-n.( jj ) .

${ }^{4}$ Esna III, 355, 6.

${ }^{5}$ Esna III, 107, 2.

- 87 - Remarks on the Concept of Wind in the Texts of the Temple of Esna 


\section{$x \times=-7=$ -}

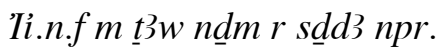

"Who came with the sweet wind to ripen the corn". 1

4- Wind is the power which makes the boat of Re navigates to the heaven. In the same context Khnum of Esna was the ferryman or the custodian of the boat:

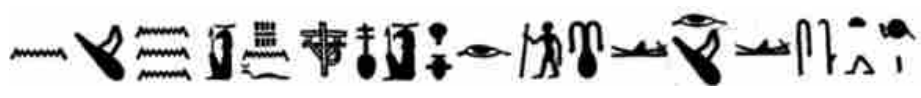

$N \underline{H} n m$ p3 nfw nfr hry-ib mndt ir-ḥmw skd $R^{\top}$.

"O, Khnum, the good wind, who is in the mid of the evening boat, the good rower $^{2}$ for walking Re". 3

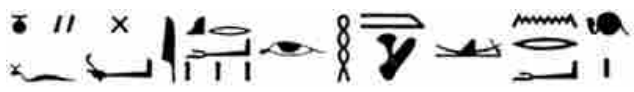

$n f w$ ikr iry- hmmw $n R^{e}$.

"The excellent wind, the good rower of Re". 4

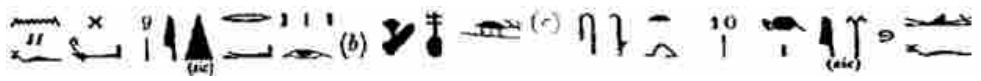

nfw ikr iry- hmww nfr skd $R^{e} m$ wỉ f.

"The excellent wind, the good rower for walking Re in his sacred boat"

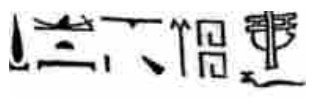

d3i pt t3 $m h h, f$.

"Who crosses the heaven and the earth on his wind". 6

5- Wind is the force of labor. On an attempt to reveal what happens during the birth of children, the ancient Egyptians imagined that the invisible force, which makes babies and placenta pass through the cervix, is the wind of god. Here, Khnum of Esna and Shu associated with each other in the chapel of Pr-msxnt due to their nature as air-gods who give labour-force to the mother. The following texts explain these features:

\footnotetext{
${ }^{1}$ Esna II, 191, 18.

${ }^{2}$ For this title; cf., Esna 277, 24; 378, 20. For Iry-Xnm as a synonymous to this title see, Esna III, $232,2$.

${ }^{3}$ Esna III, 232,

${ }^{4}$ Esna VI, 479, 15.

${ }^{5}$ Esna VI, 479, 9-10.

${ }^{6}$ Esna III, 268, B.
} 


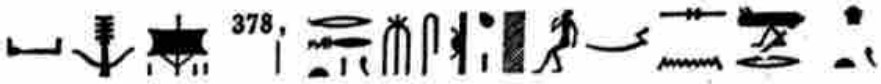

di hnmm $r \underline{h} t$ ms s3 m sni $r$ it.

"Who gives the breath to the body (womb) to o give birth the son in resemble of the father". 1

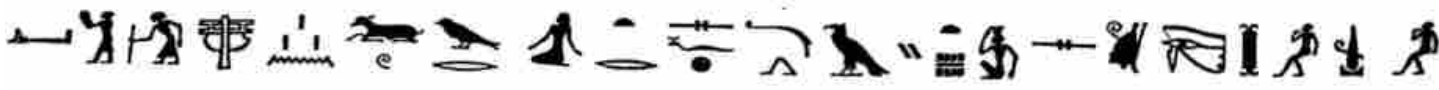 $\therefore=$ 回

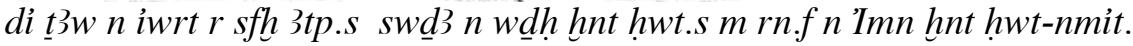

"Who gives the wind to the pregnant to loosen her load (pregnancy); he protects the weaned child before her mansion in his name Amun, the foremost of the bed".

\section{- 10 阝}

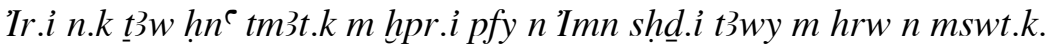

"I give you the wind with your mother in that my form of Amun, I illuminate the earth in the day of your birth". ${ }^{3}$

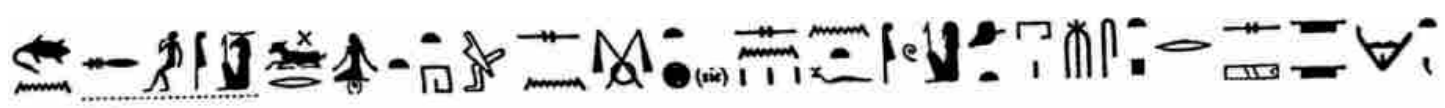

snd $n$ Hnm iwrt thi.sn dmdt.sn ntf $\breve{S} w$ hnt Pr-mst r sni k3t.

"Fear from Khnum, the pregnant who trespass their appointed time, he is Shu, the foremost of the house of birth to open the wombs". 4

6- Wind is the life force. Khnum of Esna is the god who breezes breathe to the fetus within wombs through the wind which he pushes from his mouth. Many texts point to this function:

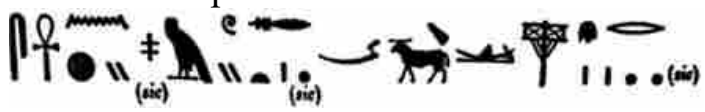

$s^{\top} n h$ h imy hl $m \underline{t} \underline{3} w$ tp r.f.

"He causes what in the body (womb) survive by the wind upon his mout". 5

\footnotetext{
${ }^{1}$ Esna III, 378, 14; Cf. rdi TAw Hr msxnt, "who gives the wind in Meskhent", Phila I, 175, 5, 187, 4, 194, 14. Urk VIII, 132k.

${ }^{2}$ Esna III, 377, 4.

${ }^{3}$ Esna III, 300, 3.

${ }^{4}$ Esna III, 366, 2.

${ }^{5}$ Esna III, 378, 17.
}

- 89 - Remarks on the Concept of Wind in the Texts of the Temple of Esna 
$\gamma_{\text {min }}^{\prime \prime}$ '

$\underline{t} 3 w n{ }^{\top} n h{ }^{\top} k m h^{\top} w m 33 m h t n$ iwrt.

"The wind of life which enters the limbs to see who is in the womb of pregnant".

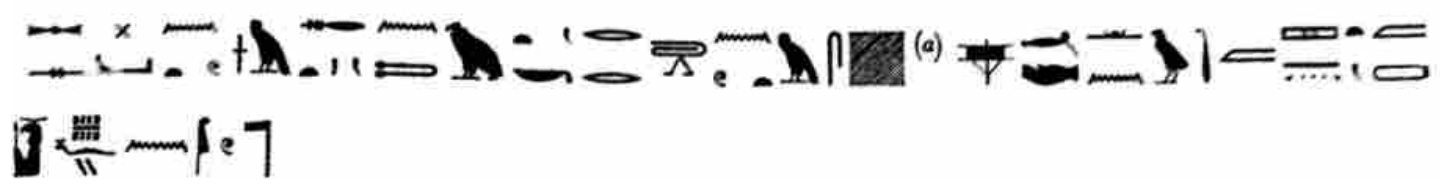

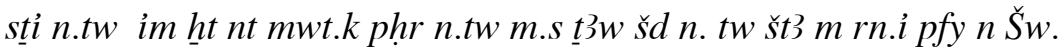

"I made you inside the belly of your mother, I made the breath of air go round for you, I nourished you in the womb by this name of me Shu".2

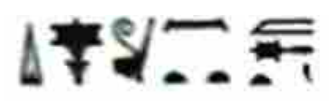

di $\underline{t} 3 w$ n nty $m \underline{h} t$.

"Who gives the wind to the one who is in the body (womb)". 3

7- Wind is the breath of resurrection in the hereafter :

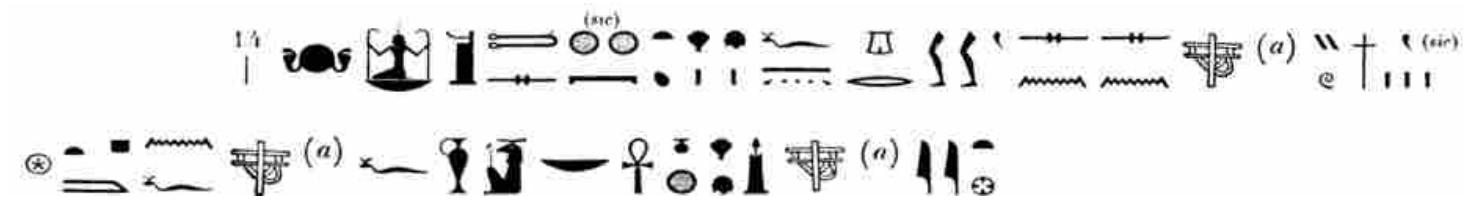

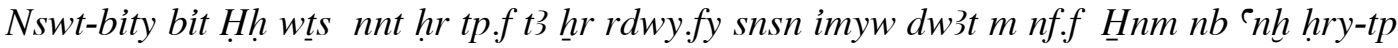
Iwynt

"King of Upper and Lower Egypt, Heh who raises the sky upon his head and the earth under his feet, the owner's who are in the Underworld breeze from his breath, Khnum, lord of life, chief of Esna". 4

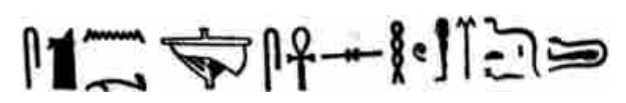

$s h n \underline{t} 3 w s^{\top} n h \underline{h} s^{\top} h w w d \underline{d} t . f \underline{d} t$.

The wind which protects and makes the mummy to live in his body eternity". 5

\footnotetext{
${ }^{1}$ Esna III, 378, 13.

${ }^{2}$ Esna III, 300, 2.

${ }^{3}$ Edfou III, 63, 11-12

${ }^{4}$ Esna VI, 522, 14. For the same sense, PT, 669; Allen, T. G., The Book of the Dead or going forth by day, saoc 37, Chicago, 1974, spell 151b. 183a. Another spell mentions that the deceased was given the breath of life since he came forth from the womb of Nut: Allen, T. G., The Book of the Dead, 182s.

${ }^{5}$ Esna III, 377, 21.
} 


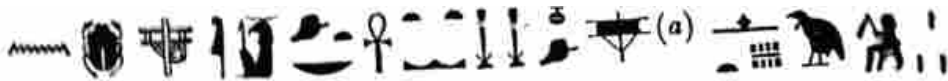

$N \underline{H} n m$ hnt $n b$ `nh snsn fnd ț $3 w$ htptyw.

"O, Khnum, the foremost of Nebanek (necropolis), who causes the nostrils of the dead ones breathing". 1

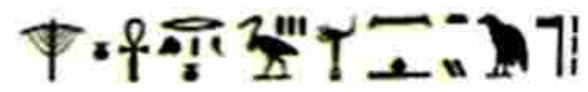

ţ3w $n$ ' $n h \operatorname{r}$ fnd $n$ b3w srk htyt $n$ htptyw.

"The breath of life to the nostril of the bas and to open the throat of the dead ones to breath". ${ }^{2}$

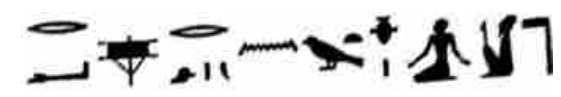

rdi țw r fnd $n$ wrd-ib.

"Who gives the wind to the nose of Osiris".

8- Wind is the merciful wind which the god sends to commiserate the distressed. The texts read:

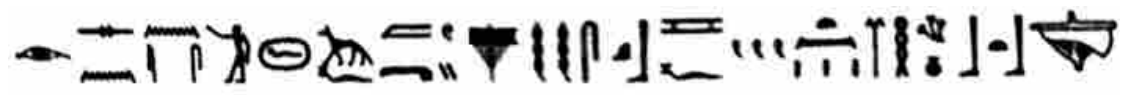

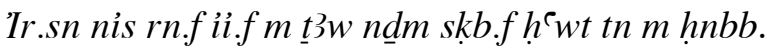

"When they call his name, he comes like the sweet wind to cool your limbs with the cool wind". 4

\section{$\Delta+\bar{\nabla}-i=11 \%$}

di $\underline{t} 3 w$ r fnd $n$ g $3 y$.

"Who gives the breeze to the nose of one who lacks it". 5

9- Wind is the beautiful sound which the sistera gives to make the heart of the god cool and satisfied. The texts read:

${ }^{1}$ Esna III, 232, 5.

${ }^{2}$ Edfou IV, 259, 8-9.

${ }^{3}$ Esna III, 241, 23.

${ }_{5}^{4}$ Esna III, 355, 3.

${ }^{5}$ Esna III, 388, 9; cf. Edfou VIII, 19, 4. A similar expression is used today in the colloquial Arabic: يداوي "to heal the wound of the heart"

\footnotetext{
- 91 - Remarks on the Concept of Wind in the Texts of the Temple of Esna
} 


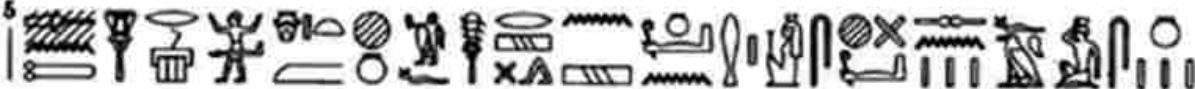

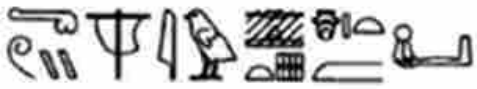

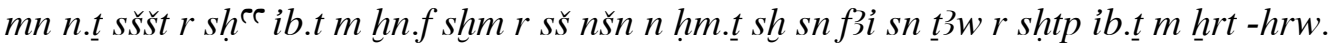

"May you receive seshest-sistra to rejoice your heart by its music, the sekhem sistra is to suppress the anger of your majesty; they hit and present the wind to rest your heart daily". 1

10 - The wind is the breath of life.

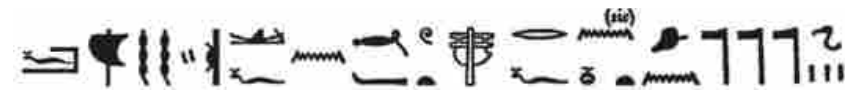

pr ț $3 w$ nd $\underline{d}$ im.f $n$ mht $r$ fnd $n$ ntrw rmt.

"The sweet wind of the north comes forth from him to the nostrils of the deities and people". 2

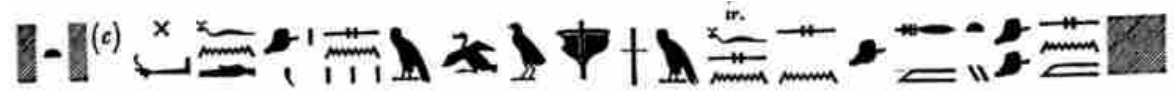

[ith].ffnd.sn $m \underline{\underline{t} 3 w}$ im.f snsn hnmty.sn $m$ [..].

"He fills their nostrils with the wind (which comes forth) from him, their noses breathe from $[\ldots]$ ". 3

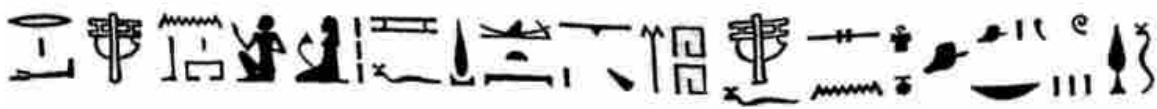

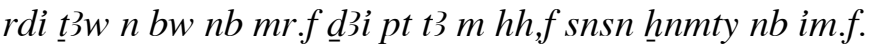

"Who gives the wind to the people whom he loves, who cross the heaven and the land on his wind, all nostrils breathe from him". 4

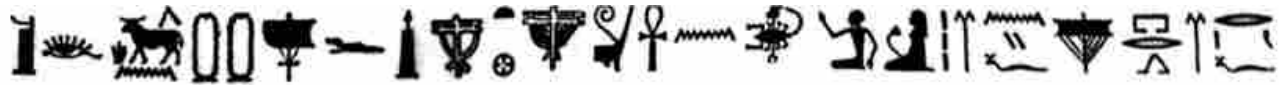

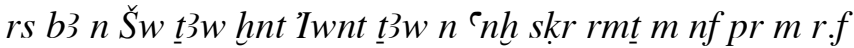

"Wake up, o the ba of Shu in front of Esna, the breath of life which makes the throat of people to breathe from the wind which comes forth from his mouth". 5

\footnotetext{
${ }^{1}$ Esna VII, 582, 5 .

${ }^{2}$ Esna III, 378, 10

${ }^{3}$ Esna II, 17, 31 .

${ }^{4}$ Esna III, 268, B.

${ }^{5}$ Esna III, 259, 5.
} 


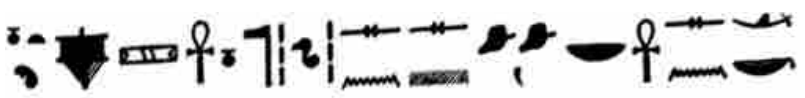

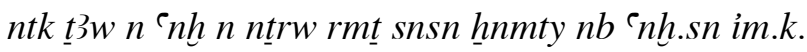

"You are the breath of life to the deities and people, every nostril breathes and lives from you". 1

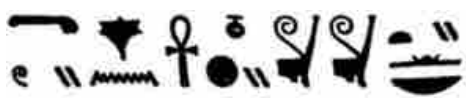

țw $n$ `nh $n$ nty $n b$.

The breath of life to all existences". ${ }^{2}$

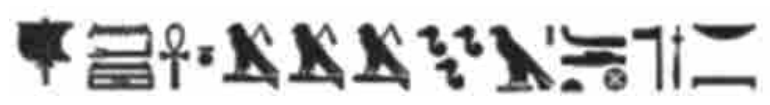

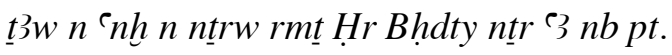

"The breath of life of the deities and people, Horus Behdety, the great god, lord of the sky". 3

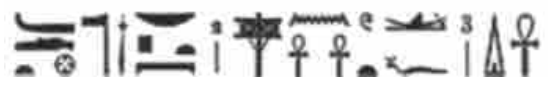

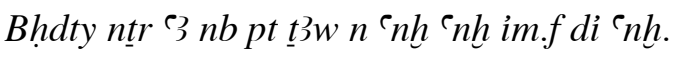

"Horus Behdety, the great god, lord of the sky, the breath of life from him, who gives life". 4

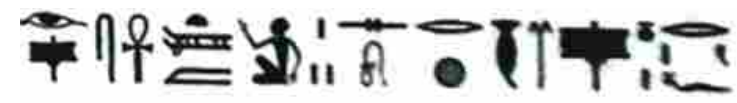

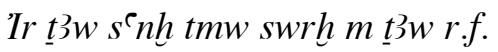

"Who creates the breath to make people live and refresh by the wind of his mouth". 5

11- Wind is the southern boundary of the reigning pharaoh. This aspect was revealed in the texts of Edfu:

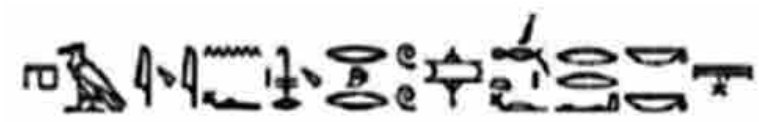

hyn n.f rsy r-d $r w \underline{t} \underline{3} w$ mht ff $r$ r-e $k k w$.

"His southern boundary is to the limit of the wind; his northern wind is to the limit of the darkness". 6

${ }^{1}$ Esna II, 156, 17.

${ }^{2}$ Esna II, 180, B.

${ }^{3}$ Edfou V, 147, 7-8; Cf. Edfou VIII, 31, 13

${ }_{5}^{4}$ Edfou, V 211, 8; 259, 7; Cf. Edfou II, 24, 123.

${ }^{5}$ Edfou III, 145, 10-11.

${ }^{6}$ Edfou II, 24, 132; 35, 13; 95, 2-3.

- 93 - Remarks on the Concept of Wind in the Texts of the Temple of Esna 


\section{CONCLUSION}

The former texts indicate that wind was an invisible and vital power of the deity who produced the first creation from his spittle or the breath which came forth from his two lips. This mythical breath was the moving power for the creation of the universe to shape the creatures. The northern wind, which helps in the navigation of the sun-god's boat during his nightly journey, grantees the continuity of the Egyptian cosmos. The god's breath was a vital force which helps babies and placenta to pass through the cervix in labor time. This philosophy reflects the mercy of the god who helps usually in hardship. This help came in the form of a sweet wind which touches the distressed hearts. The texts which have been studied above showed that the ancient Egyptian was expert with botany. The different texts represented wind as a force which makes the plants to be bloomed and grains to be grown.

Wind is linked to the underworld. It is the breath of resurrection as the first soul breathed into the baby. The same process can be imagined to provide the died boy with the breath of life to reawaked him up from the Death.

A few texts assert that the beautiful sound, which makes the deities cool and satisfied, is the wind which arises from the sistera. Wide documents used the term of wind to indicate the limit of the king's domain. In Egypt, the path of the wind seems to blow from one end of the earth to another. The texts depict the southern boundary with wind and the northern limit with the limits of darkness. The textual evidence which has been discussed, indicate that wind is strongly linked to Khnum, Menhet, Heka, Osiris, Amun and Shu-em-hery at Esna. ${ }^{1}$. This relationship could be attributed to the nature and the function of the god as it is the case with the air-god Shu or the primeval feature as it is the case with the rest of the deities who caused to make the wind blows in the primeval time.

${ }^{1}$ She bears the titles nbt TAw lady of the wind, see Edfou IV, 109,5; nDmt TAw, sweet of wind, see, Edfou XV, 56. 


\section{REFERENCES}

- Allen, T. G., The Book of the Dead or going forth by day, SAOC 37, Chicago, 1974.

- Cauville, S., Dendera, XI, Les chapelles occidentales de l'hypostyle, IFAO, Le Caire, 2000.

- Chassinat, E., Le temple d'Edfou. 14 volumes. Mémoires publiés par les membres de la mission archéologique française au Caire. Cairo: Institut français d'archéologie orientale : 1897 - 1934.

- De Morgan, J., Kom Ombos, Catalogue des monuments et inscriptions de l'Egypte antique, 3 vols. , Vienne, 1895-1905.

- De Wit, "Les génies des quatre vents au temple d'Opet m", Chron Eg 32, 1957.

- Daumas, F., Le temple de Dendera, IX, Le Caire 1987.

- Gutbub, Kôm-Ombo I, Les inscriptions du naos (sanctuaires, salle de l'ennéade, salle des offrandes, couloir mystérieux), IFAO, 1995.

- Erman, A. \& Grapow H., Wörterbuch der Ägyptischen Sprache, 7 Bde, Berlin, 1971.

- Gutbub, A., "Die Vier Winde im Tempel von Kom Ombos", in: Othmar Keel (ed.), Jahwe-Visionen und Siegelkunst, Eine neue Deutung der Majestatsschilderungen in JES 6, Ez 1 und 10 und Sach 4, Stuttgarter Bibelstudien 84/85, Stuttgart: Verlag Katholisches Bibelwerk, (1977), 328-353.

- Haikal, F., "An Unusual Ostracon from The Beit El-kretleya Museum”, in: Homenages $a^{\prime}$ Jean-claude Goyon, IFAO, 2008, 242-245.

- Kurth, D., Die Inschriften des Tempels von Edfu VII, Wiesbaden 2004.

- Montet, P., Géographie de l'Égypte ancienne, II, Paris: Librairie C. Klincksieck, 1961.

- Bénédite G., Le temple de Philoe, MMAF 13, fasc. 1-2, Paris: Leroux, 1893.

- Riggs, Ch., "Archaism and Artistic Sources in Roman Egypt. The Coffins of the Soter Family and the Temple of Deir el-Medina m", BIFAO 106 (2006), 315-332.

- Sauneron, S., Le temple d'Esna, 8 vols. , Le Caire: IFAO, 1959-1969.

- __ "Villes et legends d'Egypte", BIFAO 62(1962) pp.33-37.

- Sethe, K., Die Altägyptischen pyramiden texten, 2 Vols, J.C. Hinrichs'sche Buchhandlung. Press, Leipzig. 1908-1910.

- ___ Urkunden des Alten Reichs, Hinrichs'sche Buchhandlung Press, Leipzig. 1933.

- Woodhouse, S., The Sun God, His Four Bas and the Four Winds in the Sacred District at Sais: the Fragment of an Obelisk (BM EA 1512), in S. Quirke (ed.), The Temple in Ancient Egypt. New Discoveries and Recent Research, London, 1997.

- 95 - Remarks on the Concept of Wind in the Texts of the Temple of Esna 